\title{
Involvement of Adaptive Mechanism and Efflux-Transport System of Pseudomonas sp. LE2 Counteracting Insecticide Lindane
}

\author{
In Seon KIM, ${ }^{*}$ Byung-Taek $\mathrm{OH}^{\dagger}$ and Ro Dong PARK ${ }^{\dagger+}$ \\ Department of Environmental Science and Engineering, Kwangju Institute of Science and Technology \\ (K-JIST), 1 Oryong-dong, Puk-gu, Kwangju 500-712, South Korea \\ ${ }^{\dagger}$ Department of Civil and Environmental Engineering, The University of Iowa, Iowa City, \\ Iowa 52242-1527, USA \\ ${ }^{+\dagger}$ Division of Applied Bioscience and Biotechnology, Institute of Agricultural Science and Technology, College \\ of Agriculture and Life Science, Chonnam National University, Kwangju 500-757, South Korea
}

(Received March 28, 2002 ; Accepted May 22, 2002)

\begin{abstract}
Adaptive mechanism and efflux-transport system of Pseudomonas sp. LE2 were investigated to understand how this microorganism survives in lindane-contaminated environments. Adaptive mechanism was demonstrated by changes in the ratio of total saturated to unsaturated fatty acids in cells grown on glucose with or without lindane. The ratio of total saturated to unsaturated fatty acids in cells grown with lindane was 0.9 , which was comparable to 0.5 in cells grown without lindane. Lindane significantly affected in vitro the membrane of cells grown without lindane by decreasing membrane transition temperature from about 25 to $22^{\circ} \mathrm{C}$ at $8 \mu \mathrm{M}$. Less fluidizing effect of lindane on the membrane of cells that had grown with lindane was observed, giving about $18 \%$ of polarization percentage ratio, which was significantly lower than about $52 \%$ in cells grown without lindane. When lindane was incubated with Pseudomonas sp. LE2 cell suspensions, it accumulated in cells by simple diffusion mechanism. A membrane transport inhibitor, sodium azide, increased considerably lindane accumulation in cells, showing significant inhibition of lindane efflux from cells. These results suggest the view that Pseudomonas sp. LE2 capable of growing in the presence of lindane is able to adapt to the fluidizing action of lindane by incorporating saturated fatty acids into membrane lipids and eliminating lindane from cells by an energy-dependent efflux mechanism.
\end{abstract}

Key words: insecticide, lindane, Pseudomonas.

\section{INTRODUCTION}

Lindane is an organochlorine insecticide that has been used worldwide in agriculture since 1940s. Lindane is moderately persistent and recalcitrant in soil environment. Most countries have prohibited the use of lindane due to its toxicity and persistence. However, lindane has been still found in many sites throughout the world. ${ }^{1,2)}$ Some countries are, moreover, presently using lindane for economic reasons, which results in newly contaminated sites. Environmental contamination by widespread use of lindane is a possible concern of toxicity to human health. ${ }^{3,4)}$ Therefore, many efforts have been carried out on bioremediation technology to remove lindane from the environment. ${ }^{5,6)}$

In contamination soils, microorganisms are generally

\footnotetext{
* To whom correspondence should be addressed.
}

exposed to a complex mixture of hydrocarbon pollutants including aliphatic, aromatic and heteroatomic compounds. Many compounds are hydrophobic and lipophilic, exhibiting a high partitioning to bacterial cell membranes due to high octanol-water partition coefficients $\left(\mathrm{K}_{\text {ow }}\right)$. Hydrocarbons accumulate in the bacterial cytoplasmic membrane, resulting in alteration of membrane organization, and leading to membrane toxicity of hydrocarbons. ${ }^{7)}$

The effects of lipophilic compounds on the integrity of membranes have also been well documented for insecticides. For example, a lipophilic insecticide, such as 1,1-bis( $p$-chlorophenyl)-2,2,2-trichloroethane (DDT), induces perturbation of the membrane lipid bilayer by increasing membrane fluidity. ${ }^{8,9)}$ Insecticide parathion changes membrane fluidity by disordering membrane lipid bilayer, consequently resulting in toxicity through a biochemical mechanism. ${ }^{10)}$ The fluidizing effect of lipo- 
philic compounds on membranes leads to cells death by changing membrane organization in a way of increasing passive proton flux. ${ }^{11}$ Lindane also partitions into membranes and induces the fluidizing effect. ${ }^{12,13)}$

Microorganisms have developed a variety of strategies to survive in contamination environments. One mechanism for microorganisms to adapt to membrane-active agents and/or changing environmental conditions is to alter the lipid compositions of their membranes, thereby properly modifying membrane fluidity. ${ }^{14-16)}$ Another mechanism allowing microorganisms to survive in hydrocarbon environments is active efflux system, which eliminates hydrocarbons from cells. ${ }^{17-19)}$ These two mechanisms are clearly of fundamental importance in bioremediation processes given the environment contaminated by a complex mixture of pollutants. In such environments, microorganisms are expected to transport their preferred energy source for growth by simultaneously eliminating toxic compounds from their cells.

Although microbial degradation of lindane has been studied, little information is known on the microbial mechanisms of survival in the presence of lindane. In this report, we studied adaptive mechanism and lindaneefflux by bacteria that were isolated from lindanecontaminated soil in an effort to better understand the mechanism how microorganisms can survive in environments contaminated by lindane. We used microorganism incapable of degrading lindane, but capable of growth in the presence of lindane, to avoid complications due to degradation kinetics of the substrate in the interpretation of the substrate transport mechanism.

\section{MATERIALS AND METHODS}

\section{Chemicals}

[UL- ${ }^{14} \mathrm{C}$ ] Lindane (sp. act. $20 \mathrm{mCi} / \mathrm{mmol}$ ) and unlabeled lindane were purchased from Sigma Chemical Co. (St. Louis, MO.). The radiochemical purity was confirmed to be greater than $97 \%$ by TLC (thin-layer chromatography) and autoradiography. The molecular probe 1,6-diphenyl-1,3,5-hexatriene (DPH) used for membrane fluidity measurement was purchased from Molecular Probes Inc. (Eugene, OR, USA). Sodium azide (Fisher Scientific) was used as an inhibitor of lindane transport. All chemicals used in this study were of analytical grade, unless otherwise stated.

\section{Bacteria Isolation and Growth Conditions}

Microorganisms were isolated from lindanecontaminated soil by enrichment method as described previously. ${ }^{6)}$ Briefly, ten grams of lindane-contaminated soil was placed in a $250-\mathrm{ml}$ flask containing $50 \mathrm{ml}$ mineral salt medium (MSM) $\left.{ }^{6}\right)$ and $10 \mathrm{mg} / \mathrm{L}$ lindane. The flask was incubated at $25^{\circ} \mathrm{C}$ on rotary shaker at 250 rpm for one month. After one month-incubation, four subcultures $(10 \%$ inocula, $v / v)$ were inoculated into 50 $\mathrm{ml}$ MSM containing $1 \%(\mathrm{w} / \mathrm{v})$ glucose and $10 \mathrm{mg} / \mathrm{L}$ lindane, and incubated for 7 days as described above. The cultures were inoculated every four days for 28 days into fresh MSM containing 1\% (w/v) glucose and $10 \mathrm{mg} /$ $\mathrm{L}$ lindane. The cultures were then streaked onto MSM plates with $1 \%(\mathrm{w} / \mathrm{v})$ glucose and $50 \mathrm{mg} / \mathrm{L}$ lindane, onto which lindane was applied using a hockey stick. Seventeen isolates that showed growth in the presence of lindane were selected and restreaked several times to fresh MSM plates with $1 \%(\mathrm{w} / \mathrm{v})$ glucose and $50 \mathrm{mg} / \mathrm{L}$ lindane as described above. Lindane-nonmetabolizable isolates were selected by replica-plating onto MSM plates containing $50 \mathrm{mg} / \mathrm{L}$ lindane. Three colonies showed no growth on MSM plate containing lindane as the sole carbon source, suggesting that the colonies were lindanenonmetabolizable, but capable of growth on glucose in the presence of lindane.

Colonies that could not grow in the MSM plates containing lindane as the sole carbon source were purified several times on glucose plates, and their growths were reconfirmed in MSM with $1 \%(\mathrm{w} / \mathrm{v})$ glucose as the sole carbon source either in the presence or absence of lindane. One culture that showed the fastest growth in the presence of lindane as compared to the others was selected for further experiments. Preliminary studies showed no degradation of unlabeled lindane or $\left[{ }^{14} \mathrm{C}\right]$ lindane by this microorganism, as judged by gas chromatographic or TLC analysis. ${ }^{20)}$ The isolate was identified as Pseudomonas sp. strain by MIDI microbial identification method ${ }^{21)}$ and standard procedures, ${ }^{22)}$ and was later named Pseudomonas sp. LE2. To prepare standard culture for experiments, Pseudomonas sp. LE2 was grown in $100 \mathrm{ml}$ of $1 \%(\mathrm{w} / \mathrm{v})$ glucose in a $250-\mathrm{ml}$ flask at $25^{\circ} \mathrm{C}$ by shaking at $200 \mathrm{rpm}$. Cells were harvested in late-exponential phase by centrifugation at $6400 \times$ $g$ for $10 \mathrm{~min}$, washed three times in sterile $0.1 \mathrm{M}$ phosphate buffer ( $\mathrm{pH} 7.0$, hereafter buffer) and resuspended in the same buffer. The cell suspension was used for the lindane transport assay, determinations of membrane fluidity, and fatty acid composition. The growth of Pseudomonas sp. LE2 was determined by measuring cell turbidity at $600 \mathrm{~nm}$.

\section{Fatty Acid Analysis}

Total fatty acids of Pseudomonas sp. LE2 grown on glucose to late-exponential phase either in the presence or absence of lindane were extracted and methyl esterified using a protocol supplied by Microbial ID, Inc. (MIDI, Newark, Delaware, USA). ${ }^{21)}$ The resulted fatty acid methyl esters (FAMEs) were analyzed by gas chromatograph (GC, Hewlett-Packard model 5890A), comparing to the standards (Sigma Chemical Co., St. Louis, MO). The oven temperature was programmed from 170 to 270 ${ }^{\circ} \mathrm{C}$ at a rate of $5^{\circ} \mathrm{C} / \mathrm{min}$, and the injector and the detector (flame ionization detector) were maintained at 250 and 
$300^{\circ} \mathrm{C}$, respectively. Analytical column was HP 5 capillary column $(0.25 \mathrm{~mm}$ i.d. $\times 25 \mathrm{~m}$ length, HewlettPackard, Avondale, PA), and the flow rate of helium as the carrier gas was $1.0 \mathrm{ml} / \mathrm{min}$. FAMEs were further analyzed by gas chromatography-mass spectrometry (GC/MS). For a given sample, three independent determinations were made, with the standard deviation being within maximum $7 \%$.

\section{Membrane Fluidity Determinations}

Membrane fluidity was determined indirectly by measuring the fluorescence polarization of the probe, 1,6-diphenyl-1,3,5-hexatriene (DPH), inserted into the cytoplasmic membranes with the method as described previously. ${ }^{16)}$ Cells grown on glucose either in the presence or absence of lindane were harvested as described above, and resuspended in buffer to give an optical density (OD) of 0.4 at $600 \mathrm{~nm}$. To assess the effects of lindane on the DPH fluorescence polarization in vitro, lindane dissolved in buffer $(1 \mathrm{ml})$ was added to $2 \mathrm{ml}$ of the cell suspension before adding the DPH probe. The concentration of lindane used for DPH fluorescence polarization assay was within aqueous soluble range.

Fluorescence polarization was measured using a Perkin-Elmer MPF-3 spectrofluorometer equipped with a thermostatted cell cuvette holder and cuvette stirrer. The excitation and emission wavelength for the DPH probe was 356 and $430 \mathrm{~nm}$, respectively. The intensities parallel $\left(I_{\mathrm{vv}}\right)$ and perpendicular $\left(I_{\mathrm{vh}}\right)$ to the vertically polarized excitation beam were recorded and the degree of polarization $(P)$ calculated from the intensity measurements by the equation: $P=\left(I_{\mathrm{vv}}-I_{\mathrm{vh}} G\right) /\left(I_{\mathrm{vv}}+I_{\mathrm{vh}} G\right)$, where $G$ was the correlation factor for instrument polarization and expressed as the ratio of vertical to horizontal measurements when the excitation light is polarized in the horizontal direction. A high value of polarization represents a high structural order or low membrane fluidity, and vice versa. No effects of probe solvents on DPH polarization were observed. A background control without the DPH probe was measured under identical conditions for each sample, which showed no detectable effects on the membrane fluidity assay. To determine the membrane transition temperature $\left(T_{m}\right)$, fluorescence polarization of DPH was measured as a function of temperature ranged from 10 to $90^{\circ} \mathrm{C}$ at a rate of 1.0 ${ }^{\circ} \mathrm{C} / \mathrm{min}$. All experiments were conducted in triplicate.

\section{Lindane Transport Experiments}

Cells grown on glucose as the sole carbon source at late-exponential phase were washed three times and resuspended in buffer as described in the previous section to give a final optical density (OD) of 2.0 at $600 \mathrm{~nm}$. Lindane transport assay was initiated by addition of 10 $\mathrm{ml}$ of cell suspension to acid-washed, ultrapure waterrinsed and sterilized $125-\mathrm{ml}$ flask containing unlabeled lindane plus $\left[{ }^{14} \mathrm{C}\right]$ lindane (approximately $8 \mathrm{KBq}$ ) in 10 $\mathrm{ml}$ of buffer. The final concentration of lindane used was below the aqueous solubility ${ }^{23)}$ to minimize the experimental complications due to adsorption. The cultures were shaken at $200 \mathrm{rpm}$, and aliquots $(1 \mathrm{ml})$ were taken at various sampling times and vacuum-filtered through glass fiber filters $(0.2 \mu \mathrm{m})$. The temperature setting used for transport assay was the same for growing cells as described above. The cells on filters were then washed three times with $2 \mathrm{ml}$ of ice-cold ethanol containing unlabeled lindane $(20 \mu \mathrm{M})$. The aliquot of filtrates was used for determination of radioactivity in external of cells. The filters were then removed and transferred to a $10-\mathrm{ml}$ scintillation vial followed by the addition of $10 \mathrm{ml}$ of ScintiVerseII cocktail (Fisher Scientific), which allowed cells to be digested overnight. The radioactivity of the digested cell mixtures was determined by liquid scintillation counting in a Beckman LS6000 scintillation. The $\left[{ }^{14} \mathrm{C}\right]$ in cell pellets were taken as $\left[{ }^{14} \mathrm{C}\right]$ transported by cells during the assay period.

To assess whether lindane transport was energydependent or independent, transport experiment was carried out either in the presence or absence of $40 \mu \mathrm{M}$ sodium azide. Sodium azide was added directly to cell suspensions during transport assay. In a preliminary study, when concentrations of sodium azide ranging from 5 to $200 \mu \mathrm{M}$ were used, $40 \mu \mathrm{M}$ sodium azide was the lowest concentration shown to sufficiently inhibit the growth of Pseudomonas sp. LE2 in glucose, but this concentration did not kill the cells. At timed intervals, 1-ml cell aliquots were taken, filtered through glass fiber filters and digested, then the radioactivity was determined as described above.

\section{RESULTS AND DISCUSSION}

\section{Fatty Acid Composition}

Microorganisms capable of adapting to toxic substances have shown biological, chemical and physical changes by modifying their membranes to maintain a proper fluid state. These modifications result mainly from alterations in the fatty acid compositions of membrane lipids. ${ }^{14-16)}$ We assayed total fatty acid compositions of Pseudomonas sp. LE2 cells grown on glucose either in the presence or absence of lindane to investigate how Pseudomonas sp. LE2 changes fatty acid composition to counteract the lipophilic action of lindane.

An increase in the ratio of saturated fatty acid to unsaturated fatty acid was observed in cells grown on glucose in the presence of lindane, resulting in a ratio of total saturated to unsaturated fatty acids of approximately 0.9 (Table 1), which was comparable to the ratio of 0.5 in cells grown on glucose in the absence of lindane. Growth on glucose in the presence of lindane led to an increase in all the saturated fatty acids of cells of Pseudomonas sp. LE2. Hexadecanoic acid $\left(\mathrm{C}_{16: 0}\right)$ was 
the predominant saturated fatty acid, representing about $30 \%$ of the total fatty acids in cells grown on glucose in the absence of lindane and up to about $39 \%$ of the total fatty acid in cells grown on glucose in the presence of lindane (Table 1). The cis/trans isomerization of double bond of a fatty acid is also a strategy for adaptation mechanism to environmental contaminants. ${ }^{24,25)}$ In our experiments, these fatty acids were not detected in Pseudomonas sp. LE2 cells. The data in our experiments suggest Pseudomonas sp. LE2 capable of adapting to the lipophilic effect of lindane by increasing saturated fatty acid compositions in cell membrane lipids.

An increase in growth temperature is known to increase the degree of saturation of membrane fatty acids in microorganisms, ${ }^{26)}$ which is due to adaptive mechanism of bacteria able to grow in changing growth temperature. Increasing temperature makes bacterial membranes more fluid, and vice versa. Therefore, microorganisms capable of growth in increasing temperature are expected to change the lipid compositions in their membranes by increasing saturated fatty acid composition in order to compensate for fluidizing effect of increasing temperature. The fluidizing effect of increasing temperature on membranes is likely similar to that of lipophilic compounds such as lindane. Therefore, changes in fatty acid composition by increasing growth temperature would resemble those of cells grown on glucose in the presence of lindane. When Pseudomonas sp. LE2 was grown on glucose at $30^{\circ} \mathrm{C}$ in the absence of lindane, the membrane fatty acid profile resembled that of cells grown on glucose at $25^{\circ} \mathrm{C}$ in the presence of lindane (Table 1). These results suggest changes in fatty acid compositions are adaptive mechanism allowing

Table 1 Percentages of total fatty acid in Pseudomonas sp. LE2 grown on glucose either in the presence or absence of lindane.

\begin{tabular}{|c|c|c|c|}
\hline \multirow{4}{*}{ Fatty acid } & \multicolumn{3}{|c|}{ Growth temperature } \\
\hline & \multicolumn{2}{|c|}{ Without lindane } & \multirow{2}{*}{$\frac{\text { With lindane }}{25^{\circ} \mathrm{C}}$} \\
\hline & $25^{\circ} \mathrm{C}$ & $30^{\circ} \mathrm{C}$ & \\
\hline & \multicolumn{3}{|c|}{$\%$ of total fatty acid } \\
\hline $12: 0$ & 1.1 & 1.9 & 2.4 \\
\hline $14: 0$ & 0.8 & 2.1 & 2.7 \\
\hline $16: 0$ & 30.2 & 37.9 & 38.8 \\
\hline 17:0 & 0.5 & 0.9 & 0.7 \\
\hline 18:0 & 1.5 & 4.3 & 3.9 \\
\hline $12: 0,2 \mathrm{OH}$ & 5.1 & 2.6 & 3.7 \\
\hline $14: 0,3 \mathrm{OH}$ & 5.7 & 5.2 & 4.8 \\
\hline $16: 1, w 9 c$ & 34.2 & 30.8 & 27.8 \\
\hline $18: 1, w 9 c$ & 20.9 & 14.3 & 15.2 \\
\hline SAT/UNSAT ${ }^{*}$ & 0.5 & 0.9 & 0.9 \\
\hline
\end{tabular}

* SAT, saturated fatty acid; UNSAT, unsaturated fatty acid including hydroxylated chain.
Pseudomonas sp. LE2 cells to counteract to fluidizing effect of lindane or increasing growth temperature.

\section{Membrane Fluidity}

Lindane is expected to induce perturbation of membrane lipid structure once it is partitioned into cell membranes, due to a lipophilic nature. The effect of lindane on membranes was determined in vitro by measuring the fluorescence polarization of the probe DPH inserted into Pseudomonas sp. LE2 cells that preincubated either with or without lindane. DPH is known to partition and locate within the membrane hydrophobic core, where it provides information on the fluid state of cell membrane. , $^{8,9,16)}$

Lindane significantly affected the membrane fluidity of Pseudomonas sp. LE2 cells grown on glucose in the absence of lindane, resulting in lowering transition temperature $\left(T_{m}\right)$ of cell membranes from about 25 to $22^{\circ} \mathrm{C}$ at $8 \mu \mathrm{M}$ (Fig. 1). This result was consistent with previous observation that lindane resulted in decreased $T_{m}$ value of native membranes by decreasing DPH polarization ratio. ${ }^{12,13)}$ The percentage ratio of DPH fluorescent polarization value in cells grown on glucose in the absence of lindane was approximately 52\% (Table 2). The percentage ratios were calculated by the equation: [(control-sample)/control $] \times 100$, where control and sample denote polarization ratios of Pseudomonas sp. LE2 cells incubated without and with $8 \mu \mathrm{M}$ lindane at 25 ${ }^{\circ} \mathrm{C}$, respectively, before adding DPH to the cell suspen-

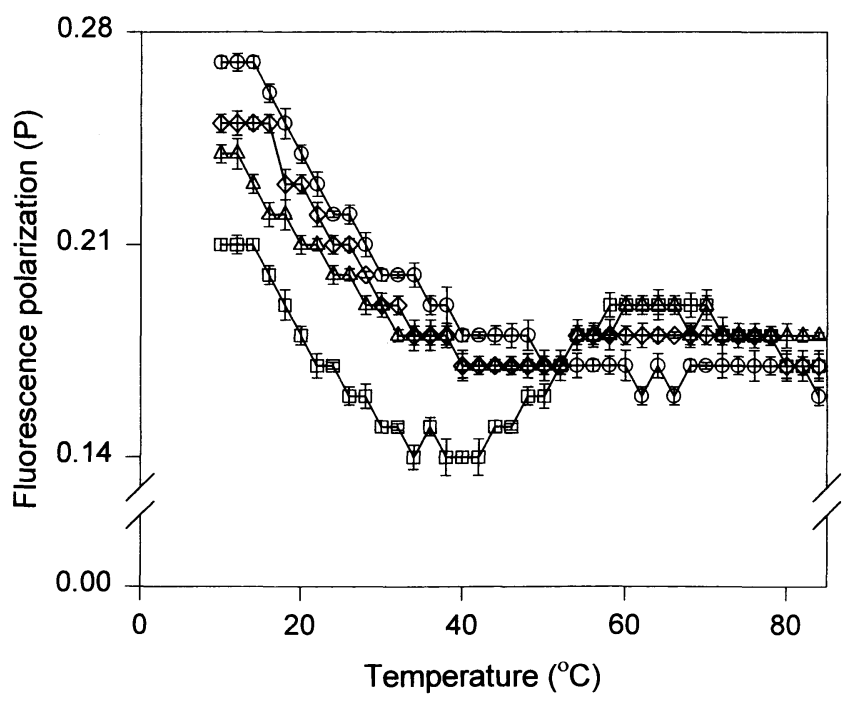

Fig. 1 Temperature dependent fluorescence polarization of DPH in membranes of Pseudomonas sp. LE2 cells grown on glucose in the absence of lindane.

Cells were incubated in the absence $(\bigcirc)$ or presence of $1(\diamond)$, $5(\triangle)$ and $8(\square) \mu \mathrm{M}$ lindane before adding DPH for polarization measurement. Polarization data are the average of three independent determinations. The error bars (if visible) represent 1 standard deviation $(n=3)$. 
Table 2 DPH fluorescence polarization ratios from Pseudomonas sp. LE2 cells grown on glucose either in the presence or absence of lindane.

\begin{tabular}{ccc}
\hline \multirow{2}{*}{$\begin{array}{c}\text { Lindane incubated } \\
(\mu \mathrm{M})\end{array}$} & \multicolumn{2}{c}{ Cells grown on glucose } \\
\cline { 2 - 3 } & In the absence of lindane & In the presence of lindane \\
\cline { 2 - 3 } 0 & $0.272 \pm 0.011$ & $0.342 \pm 0.003$ \\
& & \\
& $0.131 \pm 0.007$ & $0.281 \pm 0.012$ \\
& $(51.8 \%)^{* *}$ & $(17.8 \%)^{* *}$ \\
\hline
\end{tabular}

* Polarization data are the means $\pm \operatorname{SD}(n=3)$.

** The percentage ratios were calculated by the equation: [(control-sample)/control $] \times 100$, where control and sample denote polarization ratios of cells incubated without and with $10 \mu \mathrm{M}$ lindane, respectively, before adding DPH to the cell suspensions.

sions. Therefore, high percentage ratios in the fluorescent polarization value indicate high membrane fluidity, and vice versa.

Considerably lower ratio of DPH fluorescent polarization value in cells grown on glucose in the presence of lindane was observed as compared to cells grown on glucose in the absence of lindane (Table 2), giving the percentage ratio of about $18 \%$. These results suggest lindane had less effect on membrane polarization of cells grown on glucose in the presence of lindane. This lack of an effect is likely due to the adaptive changes in the lipid composition of the cell membranes. Indeed, a ratio of total saturated to unsaturated fatty acids in cells grown on glucose in the presence of lindane was higher than that in cells grown on glucose in the absence of lindane (Table 1). The high ratio of total saturated to unsaturated fatty acids of cells grown on glucose in the presence of lindane suggest that cells membranes become more resistant to the fluidizing action of lindane, which consequently resulted in vitro in low ratio of DPH fluorescent polarization value (18\%) as compared to cells grown on glucose in the absence of lindane (52\%). Therefore, the data from membrane fluidity assays together with the results of changes in the fatty acid composition suggest that Pseudomonas sp. LE2 cells adapt to the fluidizing action of lindane by making their membranes less fluid in the way of incorporating more saturated fatty acid into cell membranes.

\section{Lindane Transport}

Pseudomonas sp. LE2 showed adaptive changes in membrane structure by increasing the saturated fatty acid compositions in membrane lipids when cells were grown on glucose in the presence of lindane (Table 1), which consequently resulted in less fluidizing effect of lindane on membranes (Fig. 1). These adaptive changes are considered to involve in making cells more resistant to the partitioning tendency of lindane into membranes. However, there is still the possibility that lindane can partition into membranes even under such membrane status. Therefore, we hypothesized an efflux system as one possible mechanism to eliminate lindane completely from cells. To test this, lindane transport was assessed by incubating cell suspensions with $\left[{ }^{14} \mathrm{C}\right]$ lindane either in the presence or absence of sodium azide, and the distribution of radioactivity of $\left[{ }^{14} \mathrm{C}\right]$ lindane was determined in cell pellets and cell filtrates.

No time-dependence or steady-state accumulation of radioactivity of $\left[{ }^{14} \mathrm{C}\right]$ lindane was observed without sodium azide treatment (Fig. 2). The radioactivity accumulated in Pseudomonas sp. LE2 cells during the 40-min assay period was about $0.24 \mu \mathrm{mol}$ per g dry wt cells (Table 3 ). The result pattern was the same even during assay period up to $80 \mathrm{~min}$, suggesting that lindane entered cells via simple diffusion mechanism without

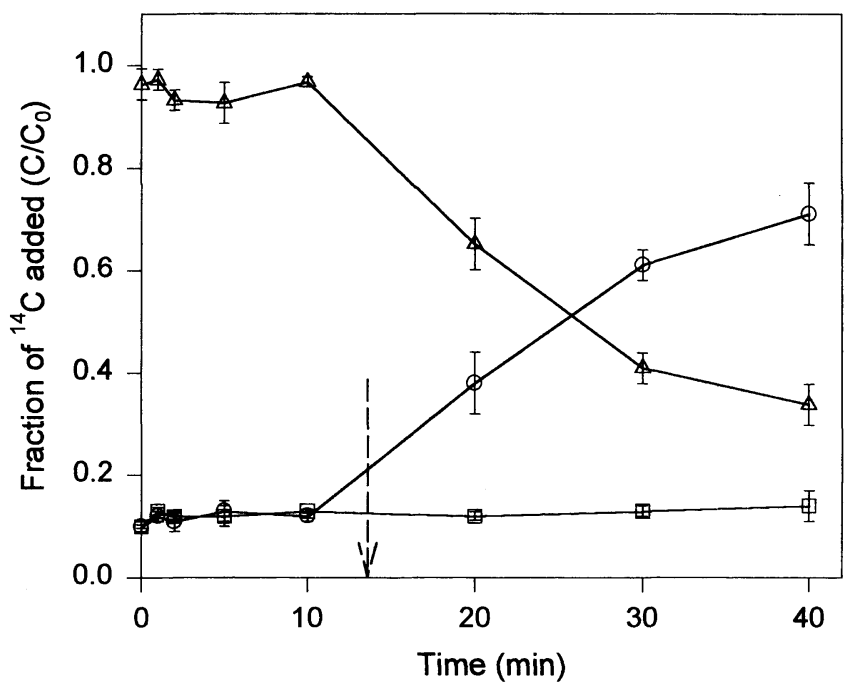

Fig. 2 Distribution of $\left[{ }^{14} \mathrm{C}\right]$ of added $\left[{ }^{14} \mathrm{C}\right]$ lindane in cell pellets and cell filtrates of Pseudomonas sp. LE2.

$\square$ : Cell pellets incubated without sodium azide; $\bigcirc$ : Cell pellets incubated with sodium azide; $\triangle$ : Cell filtrates incubated with sodium azide. The arrow-line symbol represents the time when sodium azide was added. $C_{0}$ represents $\left[{ }^{14} \mathrm{C}\right]$ added initially, while $C$ represents $\left[{ }^{14} \mathrm{C}\right]$ found in cell pellets and cell filtrates. Data are the means $\pm S D(n=3)$.

Table 3 Lindane accumulation in Pseudomonas sp. LE2 cells incubated either with or without sodium azide.

\begin{tabular}{cc}
\hline $\begin{array}{c}\text { Sodium azide added } \\
(\mu \mathrm{M})\end{array}$ & Lindane accumulation $\left(\mu\right.$ mole/g dry cell wt ${ }^{*}$ \\
\hline 0 & $0.241 \pm 0.007$ \\
40 & $1.486 \pm 0.021$ \\
\hline
\end{tabular}

* Data are the means $\pm S D(n=3)$. Lindane accumulation was assessed after incubating cell suspensions with $\left[{ }^{14} \mathrm{C}\right]$ lindane for $40 \mathrm{~min}$. 
energy supply. When cells were incubated with $\left[{ }^{14} \mathrm{C}\right]$ lindane in the presence of sodium azide, significant increase in lindane accumulation was observed in cell pellets (Fig. 2), giving approximately $1.48 \mu \mathrm{mol}$ per g dry wt cells (Table 3), which was about six times higher than that in cell pellets incubated without sodium azide. The radioactivity in cell filtrates of Pseudomonas sp. LE2 was observed to immediately decrease by addition of sodium azide (Fig. 2), suggesting inhibition of lindane elimination from cells by sodium azide treatment. Sodium azide is a membrane transport inhibitor that prevents the production of high-energy compounds needed for the active transport of substrates across cell membranes. ${ }^{19)}$ Therefore, the findings that the increased radioactivity in cell pellets and decreased radioactivity in cell filtrates by sodium azide indicate passive uptake and active efflux of lindane by Pseudomonas sp. LE2. The opposite pattern would be observed if lindane was actively accumulated in cells by energy supply.

Our data show that Pseudomonas sp. LE2 capable of growth in the presence of lindane is able to counteract the fluidizing action of lindane by changing membrane structure and eliminating lindane from the cells via an energydependent efflux system. We do not rule out the possibility that other factors such as cell envelop changes could involve in survival mechanism of Pseudomonas sp. LE2 in environments contaminated with lindane. Studies to elucidate efflux system for lindane transport and to determine the selectivity of the efflux system between lindane and other organochlorine insecticides are underway.

\section{ACKNOWLEDGMENTS}

We are indebted to Korea Science and Engineering Foundation (KOSEF), Republic of Korea, for research fellowship.

\section{REFERENCES}

1) J.-E. Haugen, W. N. Ritter and M. Schabach: Environ. Sci. Technol. 32, 217-224 (1998).

2) R. Vilanova, P. Fernandez, C. Martinez and J. O. Grimalt: J. Eviron. Qual. 30, 1286-1295 (2001).

3) S. P. Bhunya and G. B. Gena: Mutat. Res. 272, 175-181 (1992).

4) L. Silvestroni and S. Palleschi: Chemosphere 39, 1249-1252 (1999).

5) S. K. Sahu, K. K. Patnaik, M. Sharmila and N. Sethunathan: Appl. Environ. Microbiol. 56, 3620-3622 (1990).

6) J.-C. Thomas, F. Berger, M. Jacquier, D. Dernillon, F. Baud-Grasset, N. Truffaut, P. Normand, T. M. Vogel and P. Simonet: J. Bacteriol. 178, 6049-6055 (1996).

7) J. Sikkema, J. A. M. De Bont and B. Poolman: Microbiol. Rev. 59, 201-222 (1995).

8) M. D. C. Antunes-Madeira and V. M. C. Madeira: Biochim. Biophys. Acta 1023, 469-474 (1990).

9) M. D. C. Antunes-Madeira and V. M. C. Madeira: Biochim. Biophys. Acta 1149, 86-92 (1993).

10) M. D. C. Antunes-Madeira, R. A. Videira and V. M. C.
Madeira: Biochim. Biophys. Acta 1190, 149-154 (1994).

11) J. Sikkema, B. Poolman, N. Konings and J. A. M. De Bont: J. Bacteriol. 174, 2986-2992 (1992).

12) M. D. C. Antunes-Madeira and V. M. C. Madeira: Biochim. Biophys. Acta 982, 161-166 (1989).

13) M. D. C. Antunes-Madeira, R. A. Videira and V. M. C. Madeira: Biochim. Biophys. Acta 1022, 110-114 (1990).

14) S. B. Ross, M. D. C. Secco and N. E. Ghitton: Appl. Eviron. Microbiol. 40, 231-234 (1980).

15) M. M. Donato, A. S. Jurado, M. D. C. Antunes-Madeira and V. M. C. Madeira: Arch. Environ. Contam. Toxicol. 39, 145-153 (2000).

16) I. S. Kim, H. Lee and J. T. Trevors: FEMS Microbiol. Lett. 200, 17-24 (2001).

17) H. Nikaido: J. Bacteriol. 178, 5853-5859 (1996).

18) J. L. Ramos, E. Duque, P. Godoy and A. Segura: $J$. Bacteriol. 180, 3323-3329 (1998).

19) T. Bugg, M. A. Pickard, J. M. Foght and M. R Gray: Appl. Environ. Microbiol. 66, 5387-5392 (2000).

20) K. Senoo and H. Wada: Soil Sci. Plant Nutr. 35, 79-87 (1989).

21) M. Sasser: "Tracking a Strain Using the Microbial Identification System," MIS Inc., Newark, 1990.

22) J. G. Holt, N. R. Krieg, P. H. Sneath, J. T. Staley and S. T. Williams (ed.): "Bergey's Manual of Determinative Bacteriology," The Williams and Wilkins Co., Baltimore, 1994.

23) C. Tomlin: "The Pesticide Manual (10th Ed.)," p. 300, Crop Protection Public, UK. 1994.

24) H. J. Heipieper, R. Diefenbach and H. Keweloh: Appl. Environ. Microbiol. 58,1847-1852 (1992).

25) F. J. Weber, S. Isken and J. A. M. De Bont: Microbiology 140, 2013-2017 (1994).

26) H. Okuyama, N. Okajima, S. Sasaki, S. Higashi and N. Murata: Biochim. Biophys. Acta 1084, 13-20 (1991).

\section{要 約}

\section{Pseudomonas sp. LE2 の殺虫剤リンデンに対する適} 応機構と流出-輸送システムの関与

In Seon Kim, Byung-Taek Oh, Ro Dong Park

リンデンで污染された環境中で Pseudomonas sp. LE2 が どのようにして生存するのかを理解するために，本細菌の 適応機構と流出-輸送システムを調べた。適応機構は, リン デン存在下あるいは非存在下での, グルコースを含む培地 中で培養した細胞中の全飽和脂肪酸/不飽和脂肪酸の比の 変化として説明できた．In vitro では，リンデン $(10 \mu \mathrm{M})$ は細胞膜転移温度を約 $25^{\circ} \mathrm{C}$ から $22^{\circ} \mathrm{C}$ に減少させた。リン デン存在下で培養した細胞の膜においては, 減流動化効果 が観測された。 Pseudomonas sp. LE2 をリンデン存在下で 培養すると, リンデンは単純拡散機構により細胞中に蓄積 した。膜輸送阻害剤であるアジ化ナトリウムはリンデンが 細胞から流出するのを著しく阻害し, 細胞中のリンデンの 蓄積をかなり増大させた。これらの結果から, リンデン存 在下において生育能力がある Pseudomonas sp. LE2 は飽和 脂肪酸を膜脂質へ取り込み，エネルギー依存性のある流出 機構によって細胞からリンデンを排泄することが考えられ る。このことにより，この細胞はリンデンの流動化作用に 順応できることが示唆された。 